International Journal of Advanced Academic Research | ISSN: 2488-9849

Vol. 7, Issue 6 (June, 2021) | www.ijaar.org

Journal DOI: www.doi.org/10.46654/ij.24889849

Article DOI: www.doi.org/10.46654/ij.24889849.s76162

\title{
ACCOUNTING INFORMATION QUALITY AND CORPORATE PERFORMANCE OF OIL AND GAS COMPANIES IN NIGERIA
}

\author{
Macgregor, T.C. \\ Department of Accounting \\ Faculty of Management Sciences \\ University of Port Harcourt, Port Harcourt. \\ Nwaiwu, J.N \\ Department of Accounting \\ Faculty of Management Sciences \\ University of Port Harcourt, Port Harcourt. \\ Email: johnsonnwaiwu@ gmail.com, johnson.nwaiwu@ uniport.edu.ng.
}

\begin{abstract}
But knowing the unknown and therefore estimating the relationship between accounting information quality and corporate performance are still a difficult task. The aim of this empirical study is to explore the relationship between the accounting information quality and corporate performance of oil and gas companies in Nigeria. Data on different types of accounting information quality and return on equity were primarily collected from the respondents and analyzed using ordinary least square regression analysis the data with the aid of statistical package for social sciences version 25.0. The empirical result indicates that accounting information quality significantly relate to return $n$ equity; explaining about $85.1 \%$ of the total variation in return and equity. Relevance, faithful representation was each found to significantly relate to return on equity. The study empirically conclude that accounting information quality has the potency to make significant contribution to quoted financial performance of oil and gas companies and recommends that having investigated theoretical and empirical issues, also considering the findings and conclusion, the following recommendations were made: There should be need for preparers of accounting information to improve on the accounting information quality devoid of window dressing and creative accounting, regular disclosure, transparency and accountability of such accounting information is required since investors are sensitive to qualitative and quantitative accounting information in assessing the performance of quoted oil companies in and outside Nigeria. Also in line with qualitative and quantitative of accounting information quality, financial statements of quoted oil companies in Nigeria should be prepared and presented according to laid down regulations and ethical standards duly observed to ensure accounting information presented for among users, most and public consumption do represent the oil companies' economic reality during reported periods.
\end{abstract}

Keywords: Accounting Information Quality, Corporate Performance, Oil and Gas, Companies and Return on Equity. 
Journal DOI: www.doi.org/10.46654/ij.24889849

Article DOI: www.doi.org/10.46654/ij.24889849.s76162

\section{Introduction}

The question whether accounting information quality and corporate financial performance has kept researchers busy for many decades now. Most would equally agree that it started when Berle and Means (1932) started to investigate the subject. Although, the authors are quite philosophical about the topic. Later on, the question carried above becomes more interesting for researchers to look into from various different analyses. All of them have in common that the demeanor is corporate performance what differ it the factors relating to the performance of the companies they have researched. Strikingly, when one analyses the relationship between accounting information quality and corporate financial performance, it is important to define corporate financial performance. As one of the determinants, the way financial performance is measured will have a direct influence on the outcome of the equation. When analyzing the available literature on this subject it becomes clear that there are three general methods; financial performance, operational performance and overall effectiveness (Yaser., Mina \& Nar, 2014; Tailwo 2016; Esmeray, 2016; Alnajjar, 2017; Roed, 2017; Kashif, 2018; Rehad, 2018; Ahmadetil, 2020). Regarding the financial performance, which is the one that is interesting for this empirical study, two main destinations can be made (Denos; Holt \& Imhof, 2019; Manchdoh, 2019). Firstly, there are accounting based measurements; secondly, there are market measures. These measurement methods can be empirically combined to create accounting information quality.

Accounting information quality reported in annual reports is meant to show the trace and fair state of affair of any business entities so that stakeholders and other users of such information can infact take informed economic decision (Ironkwe \& Nwaiwu, 2018; Al-Dalabih, 2018). Strikingly, current accounting practices allow a degree of choices and professional judgment in determining the methods of measurement, criteria for recognition, and even the definition of the accounting information entity. The exercise of this choice can involve a deliberate nondisclosure of information and manipulation of accounting figures, thereby presenting the business as being more profitable (or less profitable for tax purposes) and financially stronger than it is supposed to be. Infact with this practice, users of accounting information quality are being misled and this constitutes a treat to corporate investment and revenue growth (Saeidi, 2014; Patal, 2015; Hla \& Teru, 2015; Ramdany, 2015; Qatanani \& Hezabr, 2015). Despite the role of the international financial reporting standards, Nigerian Accounting Standard Board and professional accounting bodies in ensuring standardized financial reports as well as compliance with financial ethics in their preparation, the problem of falsification and manipulation of accounting figures in the financial statements internationally and nationally has been on the increase (Dandago \& Rafai; Patel, 2015 Nnenna., Akpos., Viccent \& Ibinabo, 2016). Corporate organizations such African petroleum, AIG, world com, Enron, eight Nigerian banks, Lehman brothers among others disastrously collapsed as a result of corporate financial reporting malpractices investigation of these companies and oil companies revealed among others illegal corporate activities such as fraudulent accounting practices (Esmerag, 2016; Nwaiwu, 2018), presentation of complex and confusing financial statements to shareholders (Hla \& Teru, 2015; Manchdot, 2019), executive self-dealing transactions and other unethical transactions and practices (Kashaf, 2018; Manechdot, 2019). There are possibilities of window dressing and manipulation of accounting information by entities management. Relatively, the oil sector has witnessed corporate reporting failures. Despite the raft of corporate governance, quality disclosure reforms, accounting information quality on financial performance still remains murkey and some of oil companies sin Nigeria continue to find ways to play "hide-and-seek" game with the system (Sacidi, 2019; Nwachikwu, 
Journal DOI: www.doi.org/10.46654/ij.24889849

Article DOI: www.doi.org/10.46654/ij.24889849.s76162

2019). How then will the oil industry strive in a business environment where accounting records are falsified, misrepresented and unreliable given rise to investors lost of significant parts of their wealth, and less of confidence in oil business activities of reporting entities and the underlying financial reporting system.

A small number of studies existing in this area of research are output of developed countries which have different regulative framework and government mechanisms to those of Nigeria. A few of them are the studies of Saeidi (2014), Yaser., Mina and Nor (2014), Samer (2016), Tera \& Idondeyati (2017), Samer (2016), Rehab (2018) whose empirical results were mixed for example, Rehab (2018) reported that accounting information quality that are independent and active are positively related to financial performance while Al-Dalabib (2018), Skinner and Ummoren (2019) observed no significant relationship between accounting information quality and the level of financial performance. Modugu \& Eboigbe (2017) fund a positive relationship between reporting lag and profit after tax while Patal(2015),Khan (2017), Naser., A 1-Khatib \& Karbhari (2018) did not find any significant relationship between reporting lag and profit after tax. Besides, these empirical studies documented inconclusive evidence which call for an investigation into the Nigerian scenario. This provides the justification and impetus for this study. In the light of the above and with an understanding of the importance of the issues in developing countries and apparent limitations of previous studies, the current empirical cum theoretical study attempts to close the gap through an extensive study of critical accounting information quality that relates to financial performance of oil companies in Nigeria. This empirical study is sub-divided into five main sections including this introduction as section one. Section two presents the theoretical foundation, conceptual framework and empirical review on accounting information quality and financial performance; it also states the hypotheses to be tested. Section three presents the methodology, while section four reports the empirical results and discussion. Concluding remark, recommendations, limitation and suggestion for further study is in section five.

\section{Literature Review and Hypotheses Development Context.}

Theoretically, most research on the relationship between accounting information quality and financial performance of the oil and gas companies is rooted in the agency framework. Actually, the framework presumes fundamental tension between shareholders and corporate managers (Jensen \& Meckling 1976). A basic assumption of the agency theory, therefore, is that managers will act opportunistically to further their own interest before shareholders, and the basic conclusion is that the value of the firm cannot be maximized because mangers possess discretions which allow them to expropriate value to themselves (Turnbull, 1977). A collection of strictly self-invested actors implicit in the agency framework implies conflicts of interest that must be resolved through incentives, monitoring, or regulatory action.

Jensen and Meckling (1976) under agency theory, summarize these costs as being the sum of the cost of monitoring management (the agent); bending the agent to the principal (stockholder/residual claimant); and residual losses. The focus of governance in the oil and gas companies is to minimize these costs and enhance financial performance. It becomes imperative that management is constantly monitored to ensure it does not pursue policies that are inimical to the property of the enterprise. This monitoring task rests squarely with the board whose composition reflects the owners of the company. 
Journal DOI: www.doi.org/10.46654/ij.24889849

Article DOI: www.doi.org/10.46654/ij.24889849.s76162

\section{Conceptual Framework}

The idea of conceptual framework is to provide guidance or possible courses of action and approach of the research study.

\section{Return on Equity}

Return on equity reveals the earning power on the shareholders equity investment. It is obtained by dividing the profit after tax by the shareholders equity. From the point of view of the investor, it is the most important ratio because it tells in clear language what each naira of investment is yielding. And since the earning of satisfactory return is the most desirable objective of business firms, return on equity reflect the extant to which this objective is accomplished (Roed, 2017; Kashif, 2018; Manchdoh, 2019). It is of great interest to the present and prospective shareholders at the same time that it is of great concern to management which has the responsibility for maximizing the owners welfare (Denos., Holt \& Imhof, 2019). Since the benefiting shareholders are the major goal of the firm, return on equity is the accounting sense, the true bottom - line measure of performance.

Return on equity tells what percentage of profit the company makes for every monetary unit of equity invested in the company. ROE doesn't specify how much cash will be returned to the shareholders, since that depends on the company's decision about dividend payments and on how much the stock price appreciates. However, it's a good indication of whether the company is even capable of generating a return that is worth whatever risk the investment may entail (Alnajjar, 2017). ROE is usually calculated by dividing net profit by average shareholders' equity. As pointed out by Tailwo(2016), company profits are not relevant to investors except to the extent that they relate to other indicators. Aforementioned authors used ROS, ROA and ROE in order to identify a relation between effect and effort, where effect is profit while effort is given by either sales, total assets or the stockholders equity.

\section{Qualitative Accounting Information}

According to financial accounting standard board (KASB, 2000) listed eight qualitative information: (i) Relevance (ii) Reliability(iii) faithful representation (iv) understandability (v) comparability (vi) timeliness (vii) competeness (viii) verifiability. The study anchor on relevance and comparability

\section{Relevance}

Relevant accounting information is capable of making a difference in a decision by helping users' predictions about the outcomes of past, present and future events or to conform or correct prior expectations. This implies that information must possess predictive value and/or confirmatory value. Typically, FASB (2008) states that information ahs the quality of relevance when it influences the economic decisions of users by helping them evaluate past, present and future event or confirming or correcting their past evaluations. Information may be considered relevant either because of its nature or because of its materiality. The financial information is material if its omission or misstatement could affect the economic decisions of users.

According to Al-Dalabih (2018) "accounting information is relevant when it contains timely information, which means past information may not be useful to business owners and investors. Unless timely information is made available to decision makers otherwise it loses its capacity to influence decisions". This implies that if information is not available when it is 
needed or become available so long after the reported events that it ahs no value for future actions it lacks relevance and is of little or no use. Although timeliness alone cannot make information relevant, but lack of timeliness can rob information of relevance it might otherwise have had. (IASB, 2008) define relevance as he capability of making a difference in the decision made by users in their capacity as capital providers.

\section{Faithful Representation}

Statement of financial accounting concepts No. 8 highlights the fundamental quantitative characteristics of useful financial information relevance and faithful representation.

Components of faithful representation:

(i) Completeness

(ii) Neutrality

(iii) Freedom from Error

There are also various motivations for accounting information falsification. These motivations affect how phenomenon faithfully represents its economic reality. They could be classified broadly into information announcement, contractual, capital markets participation and supervisory/regulatory motivations. 


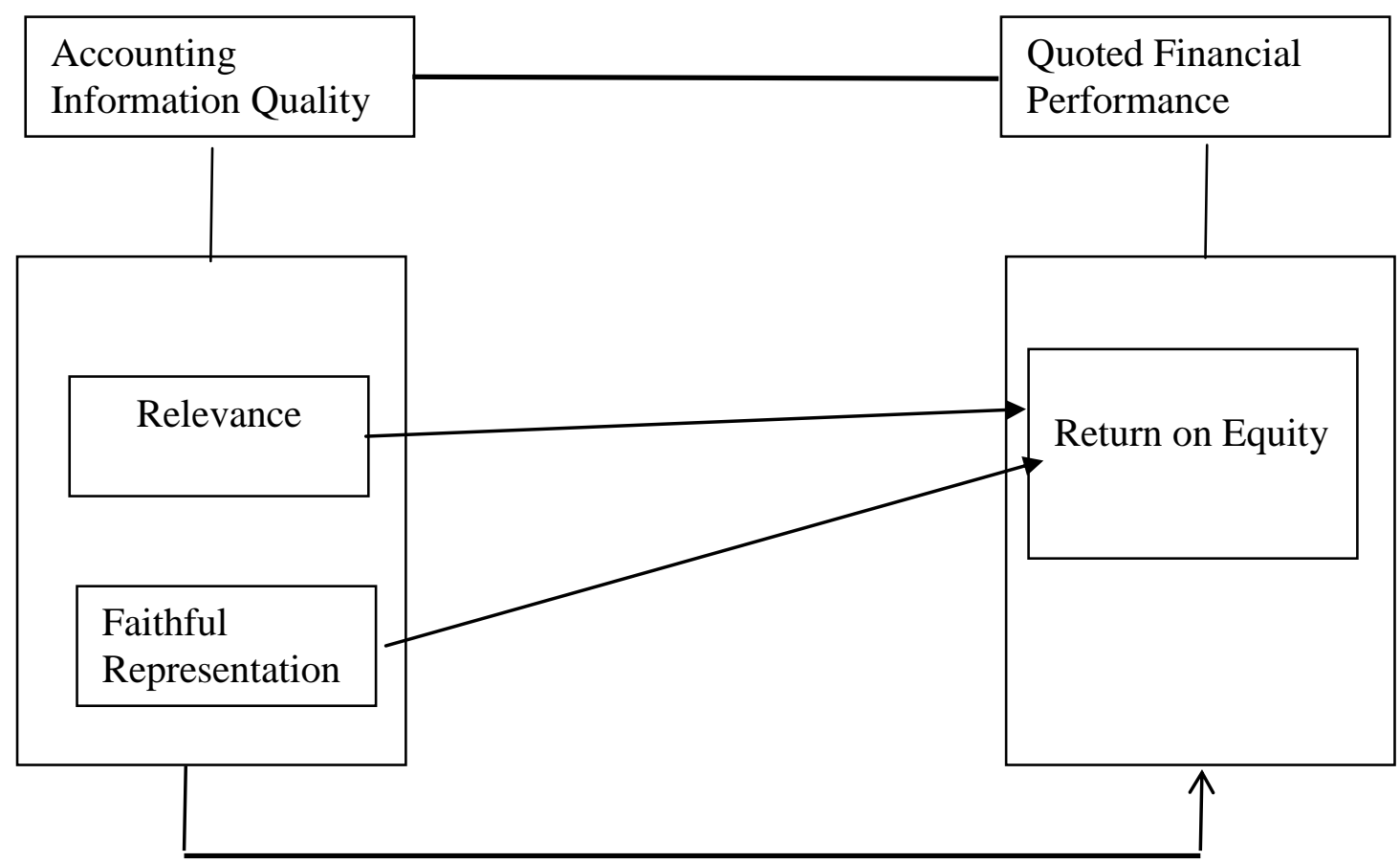

Figure 1: Operational Conceptual Framework of Accounting Information Quality and quoted Financial Performance of oil and gas companies in Nigeria.

\section{Empirical Review}

Plentitudes of investigations have established nexus of empirical studies relating to the contribution of accounting information quality and financial performance of oil companies globally with different claims and arguments. Some of the empirical studies conducted cover the impact of accounting information quality while others reviewed the effect of individual components of accounting information quality on financial performance. Notably, each group employed different statistical and econometric models to analyse the data collected deriving different empirical results and equally arriving different conclusions in the process while there were also agreements and disagreement in some of the outcomes.

Ahmad and Markson (2020), studied the effect of accounting information quality on financial performance of quoted banks in Jordan. Emphasis was focused on auditors reporting lag and disclosure on return on equity for 2014-2018. Secondary data were obtained from a sample of the ten (10), banking companies in Jordan which relatively disclosed out of twenty one (21) banks to enable content analysis. The researchers employed regression model to analyse the data and tested formulated hypotheses. Their findings indicated that there is statistically significant effect of accounting information quality on financial performance of the quoted banks in Jordan. The result specially indicated that auditors reporting lag and disclosure quality had a significant positive on return on equity. Thus, their empirical recommended that the banks should spur to focus equally on all dimensions of accounting information quality. 
Journal DOI: www.doi.org/10.46654/ij.24889849

Manchdot (2019) in his study of the relationship between accounting information quality and financial performance of quoted banks in Nigeria during the period of 2015-2019, examined the accounting information quality as part of the explanatory variables ad used auditor reporting lag as a proxy for accounting information quality. He adopted ordinary least regression method (OLRM) using the statistical package for social sciences (SPSS) version 24.0 to run the regression analysis for the period. Moreso, he claimed that there exists a significant positive relationship between all the explanatory variables (as a whole) to the profit after tax (PPT) but that there was no significant relationship between accounting information quality and financial performance. He further concluded that, there is no significant relationship between accounting information quality and financial performance and recommended that accounting information quality should be timely to the users of accounting information. However, his result did not consider if there was short run effects between the variables and indeed there was no evidence to indicate if a unit root test was conducted to test whether the panel data collected was stationary as it is important for empirical work based on time series data to assume that the underlying panel data is stationary (Khan, 2017).

Manchdat (2019) empirically studied the relationship between quality of accounting information and financial performance of quoted oil companies in Nigeria. Ex post facto research design and content analysis were adopted for the study. Secondary data were obtained from the quoted companies for the period 2014-2018 and the formulated hypotheses were tested by Pearson product moment correlation coefficient with the aid of statistical package for social sciences (SPSS) version 21. Their finding indicated significant relationship between quality of accounting information and financial performance of quoted oil companies in Nigeria. Therefore, it was recommended that accounting regulatory bodies should introduce strong quality of accounting information and reporting.

Maxwill and Wilson (2019) assessed accounting information quality and financial performance of oil marketing companies in Nigeria. Longitudinal study design was employed for the study. Secondary data was obtained from annual reports of the companies for 20042014. But multi-Binary logistic regression model was used to test the hypotheses. Their empirical finding indicated that total assets (firm size) as well as earnings per share (EPS) have positive and significant relationship with accounting information quality of oil marketing companies in Nigeria. It was also recommended that Nigerian stock exchange (NSE) should make it compulsory for the companies to set aside part of their profit for performance issues.

Table 1: Webometric Assessment of Accounting Information quality and financial performance of oil and gas companies.

\begin{tabular}{|l|l|l|l|l|}
\hline S/N & $\begin{array}{l}\text { Author's'/ } \\
\text { Year }\end{array}$ & $\begin{array}{l}\text { Count } \\
\text { ry }\end{array}$ & \multicolumn{1}{|c|}{ Journal Title } & Journal, Volume, Number \& Pages. \\
\hline i & $\begin{array}{l}\text { Ahmad, } \\
\text { Siddiqui, } \\
\text { \&, } \\
\text { Aboplsaw } \\
\text { h, (2020) }\end{array}$ & $\begin{array}{l}\text { Jorda } \\
\mathrm{n}\end{array}$ & $\begin{array}{l}\text { Family SME's survival: The role of } \\
\text { owner. Family and Corporate Social } \\
\text { responsibility. }\end{array}$ & $\begin{array}{l}\text { Journal f Small Business and } \\
\text { Enterprise Development, 27(2),281- } \\
297\end{array}$ \\
\hline ii & $\begin{array}{l}\text { Al- } \\
\text { Dalabih, } \\
(2018)\end{array}$ & $\begin{array}{l}\text { Jorda } \\
\mathrm{n}\end{array}$ & $\begin{array}{l}\text { The impact of the use of accounting } \\
\text { information system on the quality of } \\
\text { financial data. }\end{array}$ & $\begin{array}{l}\text { International Business Research, } \\
11(5), 143-158\end{array}$ \\
\hline
\end{tabular}


Journal DOI: www.doi.org/10.46654/ij.24889849

Article DOI: www.doi.org/10.46654/ij.24889849.s76162

\begin{tabular}{|c|c|c|c|c|}
\hline iii & $\begin{array}{l}\text { Budairi, } \\
\text { (2017) }\end{array}$ & Iraqi & $\begin{array}{l}\text { The effect of quality of accounting } \\
\text { information on financial statements on } \\
\text { the decisions of its users, an applied } \\
\text { study in a group of Iraqi companies. }\end{array}$ & $\begin{array}{l}\text { Al-Ghari Journal of Economic and } \\
\text { Administrative Sciences 14(1),355- } \\
388\end{array}$ \\
\hline iv & $\begin{array}{l}\text { Denos, } \\
\text { Holt, \& } \\
\text { Imholf, } \\
(2019)\end{array}$ & UK & $\begin{array}{l}\text { The use of accounting information in } \\
\text { bank lending decisions }\end{array}$ & $\begin{array}{l}\text { Accounting, } \quad \text { Organizations } \\
\text { Society, 14(3), 235-246 }\end{array}$ \\
\hline $\mathrm{V}$ & $\begin{array}{l}\text { Odar, } \\
\text { Kravic, \& } \\
\text { Jermon } \\
(2015) .\end{array}$ & $\begin{array}{l}\text { Niger } \\
\text { ia }\end{array}$ & $\begin{array}{l}\text { The role of management Accounting } \\
\text { system in decision-making process: } \\
\text { Evidence from a post-transactions } \\
\text { economy. }\end{array}$ & Engineering Economics, 26(1),84-92 \\
\hline vi & $\begin{array}{l}\text { Obaidat } \\
(2017)\end{array}$ & $\begin{array}{l}\text { Jorda } \\
\mathrm{n}\end{array}$ & $\begin{array}{l}\text { Accounting information qualitative } \\
\text { characteristics gap: Evidence from } \\
\text { Jordan }\end{array}$ & $\begin{array}{l}\text { International Management Review, } \\
3(2), 26-32\end{array}$ \\
\hline vii & $\begin{array}{l}\text { Palazuelos } \\
\text {, Crespo, } \\
\& \\
\text { Delcorte } \\
(2017) \\
\end{array}$ & UK. & $\begin{array}{l}\text { Accounting information and trust as } \\
\text { determinants of credit granting to } \\
\text { SMEs: The role of external audit. }\end{array}$ & $\begin{array}{l}\text { Small Business } \quad \text { Economics, } \\
51(4), 861-877\end{array}$ \\
\hline viii & $\begin{array}{l}\text { Kashif,(20 } \\
18)\end{array}$ & Asia & $\begin{array}{l}\text { Impact of Accounting Information } \\
\text { system on the financial performance of } \\
\text { selected FMCG companies. }\end{array}$ & $\begin{array}{l}\text { Asian Journal of Allied Sciences and } \\
\text { Technology, 2(3),8-17 }\end{array}$ \\
\hline ix & $\begin{array}{l}\text { Rehab, } \\
(2018)\end{array}$ & $\begin{array}{l}\text { Niger } \\
\text { ia }\end{array}$ & $\begin{array}{l}\text { The impact of Accounting information } \\
\text { systems on organizational performance. } \\
\text { The context of Saudi's SMEs. }\end{array}$ & $\begin{array}{l}\text { International Review of Management } \\
\text { and Marketing, 8(2),69-73. }\end{array}$ \\
\hline $\mathrm{X}$ & $\begin{array}{l}\text { Farah, } \\
\text { Farrukh, } \\
\& \\
\text { Faizan,(20 } \\
16)\end{array}$ & $\begin{array}{l}\text { Pakist } \\
\text { an }\end{array}$ & $\begin{array}{l}\text { Financial performance of firms: } \\
\text { Evidence from Pakistan Cement } \\
\text { industry }\end{array}$ & $\begin{array}{l}\text { Journal of Teaching and Education, } \\
5(1), 81-94\end{array}$ \\
\hline $\mathrm{xi}$ & $\begin{array}{l}\text { Mitchell, } \\
\text { Biykan, } \\
\text { Oniken, \& } \\
\text { Fiedler, } \\
(2017) \\
\end{array}$ & UK & $\begin{array}{l}\text { The contingency model: Criticism and } \\
\text { suggestion }\end{array}$ & $\begin{array}{l}\text { Academy of Management Journal, } \\
13(3), 1-23\end{array}$ \\
\hline xii & $\begin{array}{l}\text { Ironkwe } \\
\& \\
\text { Nwaiwu, } \\
(2018)\end{array}$ & $\begin{array}{l}\text { Niger } \\
\text { ia }\end{array}$ & $\begin{array}{l}\text { Accounting information system on } \\
\text { financial and Non-financial measures } \\
\text { of companies in Nigeria. }\end{array}$ & $\begin{array}{l}\text { International Journal of Advanced } \\
\text { Academic Research/Business } \\
\text { Development \& Management, } \\
\text { 4(2),39-55 }\end{array}$ \\
\hline xiii & $\begin{array}{l}\text { Akanbi, } \\
\& \\
\text { Adewoye, } \\
(2018)\end{array}$ & $\begin{array}{l}\text { Niger } \\
\text { ia }\end{array}$ & $\begin{array}{l}\text { Effects of Accounting Information } \\
\text { System Adoption on the financial } \\
\text { performance of central Bank in } \\
\text { Nigeria. }\end{array}$ & $\begin{array}{l}\text { Journal of Accounting \& Marketing, } \\
1(6), 1-6\end{array}$ \\
\hline xiv & $\begin{array}{l}\text { Alnajjar, } \\
(2017)\end{array}$ & $\begin{array}{l}\text { Niger } \\
\text { ia }\end{array}$ & $\begin{array}{l}\text { Impact of Accounting information } \\
\text { system on organizational performance: } \\
\text { A study of SME's in the UAE. }\end{array}$ & $\begin{array}{l}\text { Journal of Accounting \& Finance, } \\
3(1), 20-35\end{array}$ \\
\hline $\mathrm{XV}$ & Raed, & Jorda & The impact of computerized accounting & International Journal of \\
\hline
\end{tabular}


Journal DOI: www.doi.org/10.46654/ij.24889849

Article DOI: www.doi.org/10.46654/ij.24889849.s76162

\begin{tabular}{|c|c|c|c|c|}
\hline & $(2017)$ & $\mathrm{n}$ & $\begin{array}{l}\text { information system on management } \\
\text { performance in public sector in } \\
\text { Nigeria: problem \& Prospects. }\end{array}$ & $\begin{array}{l}\text { Multidisciplinary Research and } \\
\text { Development, 4(12),80-83 }\end{array}$ \\
\hline xvi & $\begin{array}{l}\text { Tera, } \\
\text { IdoNdeyat } \\
\text { i, (2017) }\end{array}$ & India & $\begin{array}{l}\text { A review of the impact of accounting } \\
\text { information system for effective } \\
\text { internal control on firm performance. }\end{array}$ & $\begin{array}{l}\text { Indian Journal of Finance and } \\
\text { Banking, 1(2),52-59 }\end{array}$ \\
\hline xvii & $\begin{array}{l}\text { Akanbi, \& } \\
\text { Adewoye, } \\
(2018)\end{array}$ & $\begin{array}{l}\text { Niger } \\
\text { ia }\end{array}$ & $\begin{array}{l}\text { Effects of Accounting information } \\
\text { system adoption on the financial } \\
\text { performance of commercial bank in } \\
\text { Nigeria. }\end{array}$ & $\begin{array}{l}\text { Journal of Accounting \& Marketing, } \\
\text { 1(6),1-6 }\end{array}$ \\
\hline xviii & $\begin{array}{l}\text { Borhan, } \\
\& \text { Nofees, } \\
(2018)\end{array}$ & $\begin{array}{l}\text { Jorda } \\
\mathrm{n}\end{array}$ & $\begin{array}{l}\text { Effects of accounting information } \\
\text { system on financial performance: A } \\
\text { study of selected real estate companies } \\
\text { in Jordan. }\end{array}$ & $\begin{array}{l}\text { India Technical Research } \\
\text { Organization, 5(1),41-50 }\end{array}$ \\
\hline xix & Isa, $(2017$ & $\begin{array}{l}\text { Niger } \\
\text { ia }\end{array}$ & $\begin{array}{l}\text { The impact of computerized accounting } \\
\text { information system on management } \\
\text { performance in public sector in } \\
\text { Nigeria: Problem and Prospects. }\end{array}$ & $\begin{array}{l}\text { International Journal of } \\
\text { Multidisciplinary Research and } \\
\text { Development, 4(1),80-83 }\end{array}$ \\
\hline $\mathrm{xxi}$ & $\begin{array}{l}\text { Khan, } \\
(2017)\end{array}$ & $\begin{array}{l}\text { Niger } \\
\text { ia }\end{array}$ & $\begin{array}{l}\text { Impact of Accounting information } \\
\text { system on the organizational } \\
\text { performance: A case study of Procter } \\
\text { and Gamble. }\end{array}$ & Star Research, 5(12),20-30 \\
\hline xxii & $\begin{array}{l}\text { Nizor, } \\
\text { Ahmad, \& } \\
\text { Mohamad, } \\
(2016)\end{array}$ & $\begin{array}{l}\text { Unite } \\
\mathrm{d} \\
\text { Arab } \\
\text { Emira } \\
\text { tes }\end{array}$ & $\begin{array}{l}\text { Evaluate of accounting information } \\
\text { systems in meeting the requirements of } \\
\text { financial and managerial performance. } \\
\text { Field study in the United Arab } \\
\text { Emirates private Hospitals. }\end{array}$ & $\begin{array}{l}\text { International Journal of Humanities } \\
\text { and Social Science, 6(4),170-196 }\end{array}$ \\
\hline xxiii & $\begin{array}{l}\text { Akesinro, } \\
\& \\
\text { Adetoso, } \\
(2016)\end{array}$ & $\begin{array}{l}\text { Niger } \\
\text { ia }\end{array}$ & $\begin{array}{l}\text { The effects of computerized accounting } \\
\text { system on the performance of banks in } \\
\text { Nigeria. }\end{array}$ & $\begin{array}{l}\text { Journal of Economics and } \\
\text { Sustainable Development, 7(14), 76- } \\
82\end{array}$ \\
\hline xxiv & $\begin{array}{l}\text { Ali, } \\
\text { Bakar, \& } \\
\text { Omar, } \\
(2016)\end{array}$ & $\begin{array}{l}\text { Jorda } \\
\mathrm{n}\end{array}$ & $\begin{array}{l}\text { The critical success factors of } \\
\text { Accounting Information System (AIS) } \\
\text { and its impact on organizational } \\
\text { performance of Jordan commercial } \\
\text { banks }\end{array}$ & $\begin{array}{l}\text { International Journal of Economics, } \\
\text { Commerce and Management, } \\
4(4), 658-677\end{array}$ \\
\hline $\mathrm{xxV}$ & $\begin{array}{l}\text { Esmeray, } \\
(2016)\end{array}$ & $\begin{array}{l}\text { Turke } \\
\mathrm{y}\end{array}$ & $\begin{array}{l}\text { The impact of accounting information } \\
\text { systems in firm performance: Empirical } \\
\text { evidence in Turkish small and medium } \\
\text { sized enterprises. }\end{array}$ & $\begin{array}{l}\text { International Review of Management } \\
\text { and Marketing, } 6(2), 233-236\end{array}$ \\
\hline xxvi & $\begin{array}{l}\text { Mahdi, } \\
\text { Mahmond } \\
\text {, Mostafa, } \\
\& \\
\text { Ebadoholl } \\
\text { ah, } \\
(2015)\end{array}$ & Iran & $\begin{array}{l}\text { The effect of implementation of } \\
\text { accounting information system on } \\
\text { efficiency, profitability and } \\
\text { productivity of SMEs in Iran. }\end{array}$ & $\begin{array}{l}\text { Banks and Bank Systems, 10(3),79- } \\
86\end{array}$ \\
\hline xxvii & Taiwo, & Niger & Effect of ICT on accounting & European Journal of Business and \\
\hline
\end{tabular}


Journal DOI: www.doi.org/10.46654/ij.24889849

Article DOI: www.doi.org/10.46654/ij.24889849.s76162

\begin{tabular}{|c|c|c|c|c|}
\hline & (2016) & ia & $\begin{array}{l}\text { information systems and organizational } \\
\text { performance: The application of } \\
\text { information and communication } \\
\text { technology on accounting information } \\
\text { system }\end{array}$ & Social Sciences, 5(2),1-15 \\
\hline xxix & $\begin{array}{l}\text { Dekeng, } \\
\& \\
\text { Prabowo, } \\
(2015)\end{array}$ & $\begin{array}{l}\text { Niger } \\
\text { ia }\end{array}$ & $\begin{array}{l}\text { Accounting information system } \\
\text { alignment and Smes performance. A } \\
\text { literature Review. }\end{array}$ & $\begin{array}{l}\text { International Journal of Management, } \\
\text { Economics \& Social Sciences, } \\
4(2), 58-70\end{array}$ \\
\hline $\mathrm{xxx}$ & $\begin{array}{l}\text { Hla, \& } \\
\text { Teru, } \\
(2015\end{array}$ & India & $\begin{array}{l}\text { Efficiency of accounting information } \\
\text { system and performance measures: } \\
\text { Literature Review }\end{array}$ & $\begin{array}{l}\text { International Journal of } \\
\text { Multidisciplinary and Current } \\
\text { Research, 3(3),976-984 }\end{array}$ \\
\hline xxxi & $\begin{array}{l}\text { Patal, } \\
(2015\end{array}$ & $\begin{array}{l}\text { Niger } \\
\text { ia }\end{array}$ & $\begin{array}{l}\text { Effects of accounting information } \\
\text { system on organizational profitability. }\end{array}$ & $\begin{array}{l}\text { International Journal of Research and } \\
\text { Analytical Reviews, 2(1),72-77 }\end{array}$ \\
\hline xxxii & $\begin{array}{l}\text { Saeidi } \\
(2014)\end{array}$ & India & $\begin{array}{l}\text { The impact of accounting information } \\
\text { system on financial performance. A } \\
\text { case study of TCS India. }\end{array}$ & $\begin{array}{l}\text { Indian Journal of Fundamental and } \\
\text { Applied Life Sciences, 4(4),412-417 }\end{array}$ \\
\hline $\begin{array}{l}\text { xxxii } \\
\text { i }\end{array}$ & $\begin{array}{l}\text { Eb, } \\
\text { Pretorious } \\
\text { \& Zuva, } \\
(2013)\end{array}$ & $\begin{array}{l}\text { Niger } \\
\text { ia }\end{array}$ & $\begin{array}{l}\text { The role of accounting information } \\
\text { system in accounting firm. }\end{array}$ & $\begin{array}{l}\text { International Journal of Accounting, } \\
\text { Advanced Computer Research, } \\
\text { 1(2),21-31 }\end{array}$ \\
\hline $\begin{array}{l}\mathrm{xxxi} \\
\mathrm{v}\end{array}$ & $\begin{array}{l}\text { Manchdot, } \\
\text { (2019) }\end{array}$ & UK & $\begin{array}{l}\text { A review of determinants Accounting } \\
\text { information system adoption. }\end{array}$ & $\begin{array}{lcr}\text { Science Journal of } & \text { Business } \\
\text { Management, 7(1),17-22 } & \\
\end{array}$ \\
\hline $\mathrm{xxxv}$ & $\begin{array}{l}\text { Dandago, } \\
\text { Rafai, } \\
(2014)\end{array}$ & $\begin{array}{l}\text { Niger } \\
\text { ia }\end{array}$ & $\begin{array}{l}\text { Information technology and } \\
\text { accounting system in the Nigerian } \\
\text { banking industry. }\end{array}$ & $\begin{array}{llll}\text { Asian Economic } & \text { and } & \text { Financial } \\
\text { Review, } 2(10), 1-9 & & \end{array}$ \\
\hline $\begin{array}{l}\text { xxxv } \\
\mathrm{i}\end{array}$ & $\begin{array}{l}\text { Samer, }(20 \\
16)\end{array}$ & $\begin{array}{l}\text { Jorda } \\
\mathrm{n}\end{array}$ & $\begin{array}{l}\text { The impact of the effectiveness of } \\
\text { accounting information systems on } \\
\text { operational performance in public } \\
\text { listed industrial companies in Jordan. }\end{array}$ & $\begin{array}{l}\text { Journal of Social Sciences, 5(3),265- } \\
276\end{array}$ \\
\hline $\begin{array}{l}\mathrm{xxxv} \\
\text { ii }\end{array}$ & $\begin{array}{l}\text { Yaser, } \\
\text { Mina, \& } \\
\text { Nor, } \\
(2014)\end{array}$ & $\begin{array}{l}\text { Niger } \\
\text { ia }\end{array}$ & $\begin{array}{l}\text { The impact of the effectiveness of } \\
\text { accounting information system in } \\
\text { Nigerian banking industries. }\end{array}$ & $\begin{array}{l}\text { Asian Economic and Financial } \\
\text { Review, 4(5), 655-670 }\end{array}$ \\
\hline
\end{tabular}

\section{Research Question and Hypotheses Development Context.}

A considerable amount of empirical studies have been conducted between accounting information quality and quoted financial performance of oil and gas companies in Nigeria. This empirical study provides answer to the following research question (Rq).

$\left(\mathrm{RQ}_{1}\right.$ : What is the nature of relationship between accounting information quality and quoted financial performance of oil and gas in Nigeria?

In line with the above stated research questions (RQ), two hypotheses stated in the null form were tested.

$\mathrm{H}_{01}$ : There is no significant relationship between relevance and return on equity of quoted oil and gas in Nigeria.

$\mathrm{H}_{02}$ : Faithful representation does not significantly relate to return on equity of quoted oil and gas companies in Nigeria. 
Journal DOI: www.doi.org/10.46654/ij.24889849

\section{Research Methods}

This section identified the research methods adopted in evaluating the significant relationship between accounting information quality and earnings per share of quoted oil and gas companies in Nigeria. The research design applied on the qualitative information quality is survey research design and the qualitative information quality were collected by means of a survey questionnaire administered on the participants. The data collected from the responses to the questionnaire were analyzed using descriptive statistics, frequencies, means, standard deviation and ordinary least square regression analysis with the aid of statistical package for social science (PSS) version 25.

\section{Model Specification.}

Based on the theoretical underpinning and empirical review of related literature made in the study, we construct a specific model that captured the relationship between accounting information quality and financial performance. The model is theoretically specified in functional form as thus:

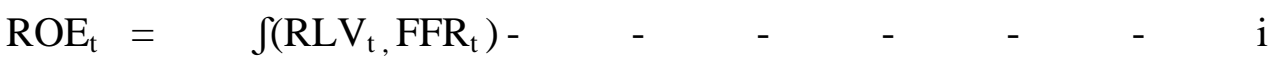

Expanding the functional into the mathematical form as thus:

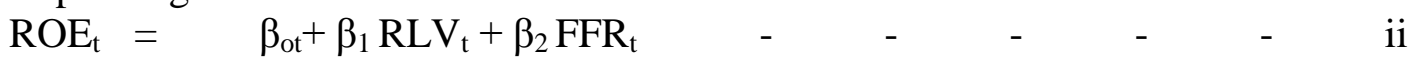

Having stated the functional and mathematical form, we introduced the econometric model as thus:

$\mathrm{ROE}_{\mathrm{t}}=\lambda_{\mathrm{ot}}+\lambda_{1} \mathrm{RLV}_{\mathrm{t}}+\lambda_{2} \mathrm{FFR}_{\mathrm{t}}+\mu_{\mathrm{t}} \quad-\quad-\quad-\quad-\quad-\quad-\quad-\quad-\quad$ iii

Where: $\operatorname{ROE}_{\mathrm{t}}=\quad$ Return on Equity for the time period

$\mathrm{RLV}_{\text {it }}=\quad$ Relevance for the time period

$\mathrm{FFR}_{\mathrm{t}}=$ Faithful Representation for the time period

$\mu_{\mathrm{t}} \quad=\quad$ Error Term for the time period

$\lambda_{\text {oit }}=$ Constant for the time period

$\lambda_{1}-\lambda_{2}=\quad$ Regression slope for the time period

it $\quad=\quad$ The time period.

\section{Validity and Reliability}

Empirical research should strive for the possible quality of data since findings and conclusions from any study are only as the data on which they are based. Hence, according to Punch (2018), "quality of data should be an "overriding consideration" in deciding the quality of research work. So every work should achieve reliability (stability of response) and validity. For the purpose of this study in which a multi-item scale was used, the relationship between constructs and their indicators were validated by experts in accounting, finance and corporate reporting.

To ensure that the test instrument is reliable and consistent, the researcher shall adopt Internal Consistency method by using Cronbach (1951) Alpha test for ascertaining the reliability of the pre-study responses collected through the research instrument shall be utilised. The test will be done through SPSS version 25.0. The data will be collected from the 40 respondents that will actively and fully participate in the pilot study will be used. The Cronbach's alpha for the research questionnaire will be determined based on the responses captured in the questionnaire. 
Journal DOI: www.doi.org/10.46654/ij.24889849

Article DOI: www.doi.org/10.46654/ij.24889849.s76162

When test items are closely related to one another, Cronbach's alpha will be closer to 1 , and when test items are not closely related to one another, Cronbach's alpha will be closer to 0 . An alpha $(\alpha)$ of $0.90-0.95$ is desirable for clinical interpretation of tests (Bland \& Altman, 1997). Below are the reliability figures for the constructs, as shown in table 3.3.

Table 3.3: Reliability Statistics for Pilot Test

\begin{tabular}{l|ccc} 
S/NO & Construct & No. Of Items & Cronbach's Alpha \\
\hline $\mathbf{1}$ & Relevance & $\mathbf{5}$ & $\mathbf{0 . 8 4 7}$ \\
2 & Faithful representation & $\mathbf{5}$ & $\mathbf{0 . 7 9 6}$
\end{tabular}

Information in table 3.3 indicates the reliability statistics for the pilot study conducted. The table shows that all the sub-constructs recorded Cronbach's Alpha values greater than the minimum threshold.

\section{Empirical Results and Discussion}

The field activity for this study entailed the distribution and retrieval of the questionnaire copies to the target Nigerian quoted oil companies. Questionnaire administration was carried out manually, entailing the researcher's personal visits; in company of research assistants, and correspondence with the target respondents within all federal government agencies specified in the study. Correspondence included telephone calls and messages to guarantee development and auspicious fruition of the procedure.

A sample size of 104 was adopted, thus 104 copies of the questionnaire were distributed to the target sample. Retrieval of questionnaire items was also achieved manually with the researcher, as well as the research assistants, visiting, collecting and collating all copies of the questionnaires; unfortunately, 8 copies of the questionnaire were considered as lost given the absence of the units during the time of questionnaire retrieval, in some cases, due to the inability of the respondents to meet up with the time window stipulated for questionnaire completion. Therefore, the study utilized a representative size of 104 in the analysis.

After retrieval, all copies of the questionnaire were duly treated for missing values, blank sections as well as double item check. These issues were addressed during the questionnaire coding phase of the study. For missing values, the mode approximation was adopted as a substantial assessment of the possible or probable choices for missing data. This process follows the assessment of previous choices and adopts values based on highest frequencies. However, its bias can be considered as statistically significant when the missing data accounts for more than $10 \%$ of the total sample size (Sekaran \& Bougie, 2010). The same treatment was also applied in cases with double item checks, with the option having the highest frequency adopted. There were no cases with blank sections.

In assessing for outliers, the study adopts the boxplot chart in ascertaining points which fall outside the stipulated scaling ( 5 - point Likert) for the study. In this sense, a lower boundary of 1 and an upper boundary of 5 is utilized in the assessment of cases and the possibility of outliers within the study. The study adopts the gender category as the base for the assessment of the data for the variables of the study. Hence, all the variables are assessed using the gender category as a base. Presented in figure 4.1, 4.2 and 4.3 are the boxplot charts for the cases. 
Journal DOI: www.doi.org/10.46654/ij.24889849

Article DOI: www.doi.org/10.46654/ij.24889849.s76162

Table 4.3: Response Rate for Field Data Collection

Activities

Copies of Questionnaires distributed

Copies of Questionnaires retrieved

Copies of Questionnaires not retrieved

Copies completed but not useable.

Copies completed and useable
Number of Occurrences

104

98

6

7

91
Percentage of

Occurrences

$100 \%$

$94.23 \%$

$5.76 \%$

$6.73 \%$

$87.5 \%$

Table 4.4: Cronbach Reliability Result

\begin{tabular}{|c|c|c|c|}
\hline Variables (latent) & Dimensions/Measures & No. of items & Alpha Coefficients \\
\hline Accounting & Relevance & 5 & .847 \\
\hline $\begin{array}{c}\text { information } \\
\text { quality } \\
\text { (Qualitative } \\
\text { Variables) }\end{array}$ & Faithful representation & 5 & .796 \\
\hline
\end{tabular}

Presented in table 4.4 is the distribution for the Cronbach alpha reliability tests for the study. The table illustrates substantial Cronbach alpha values for all instruments with the highest coefficient at .847 and the lowest at .796. The values indicate substantial levels of reliability for the instruments and indicate strong levels of instrument repetitiveness, clarity and comprehension by the oil companies' respondents.

\section{Univariate Analysis}

This section of the study presents the results on the distribution for the variables of the study. The emphasis of this section is on assessing the distribution for each of the variables as a way of understanding their prevalence and the extent to which they are manifested by the target individuals or organizations. The univariate analysis utilizes central tendencies, especially the mean $(\mathrm{x})$ in addressing the extent to which each indicator is substantially experienced and acknowledged by the respondents to be a significant feature in their activities or functionalities.

This study adopted the Likert's five (5) -point Scale, with response category from Strongly Disagree $(S D)=1$, to Strongly Agree $(S A)=5$. Asawo (2009), posited that mean values are categorized between 1.0 to 2.4 as low, 2.5 to 3.5 as moderate, $3.5-4.4$ as high and above 4.5 as very high. Oxford and Burry-Stock (1995), further categorized a Likert's five (5) - point scale data sets with mean scores of between $1.0-2.4$ as low, $2.5-3.4$ as medium, while values between $3.5-5.0$ are high.

A criterion mean of $x=3.00$ is adopted as base for the assessment of the substantiality of the variables, where $\mathrm{x}<3.00$, manifestations can be said to be unsubstantial and probably nonexistent; where $2.00<x<4.00$, manifestations can be said to be moderate but yet significant; where $4.00<\mathrm{x}<5$, manifestations can be said to be highly substantial and strongly evident. The points adopted are based on the scaling format for the study and in the same vein rank the effects or manifestations of the variables. In this way, scores $x>3.00$ will reflect apparent agreement to the statement but at differing levels while scores $\mathrm{x}<3.00$ will reflect disagreement to the statements or indicators. 
The first variable assessed is the predictor variable which is Accounting information quality. The assessment examined the extent to which the individuals and their organizations expressed or can be considered as embodying attributes which can be described as Relevance and Faithful representation. As such these dimensions are also examined using instruments that allow for the quantification and summarization of their manifestations.

Table 4.3: Distribution of Accounting Information Quality

\begin{tabular}{llrrr}
\hline \hline & & \multicolumn{2}{c}{ N } & \multicolumn{2}{c}{ Mean } & \multicolumn{2}{c}{ Stdation } \\
\cline { 3 - 5 } Relevance & RLV1 & Statistic & Statistic & Statistic \\
& RLV2 & 91 & 4.34 & .769 \\
& RLV3 & 91 & 4.30 & .694 \\
& RLV4 & 91 & 4.22 & .703 \\
& RLV5 & 91 & 4.45 & .713 \\
Faithful representation & FFR1 & 91 & 4.19 & .778 \\
& FFR2 & 91 & 4.09 & .846 \\
& FFR3 & 91 & 4.06 & .821 \\
& FFR4 & 91 & 4.33 & .739 \\
& FFR5 & 91 & 4.36 & .710 \\
& Valid N (listwise) & 91 & 4.28 & .746 \\
\hline \hline
\end{tabular}

Table 4.3: Distribution for dimensions of Accounting Information Quality

\begin{tabular}{lrrrrrrr}
\hline \hline & \multicolumn{1}{c}{$\mathrm{N}$} & Mean & Std. Deviation & \multicolumn{2}{c}{ Skewness } & \multicolumn{2}{c}{ Kurtosis } \\
\cline { 2 - 8 } & Statistic & Statistic & Statistic & Statistic & Std. Error & Statistic & Std. Error \\
\hline RLV & 91 & 4.2741 & .57538 & -1.883 & .140 & 5.281 & .180 \\
FFR & 91 & 4.2100 & .60676 & -1.754 & .140 & 4.687 & .180 \\
Valid N & & & & & & & \\
(listwise) & 91 & & & & & & \\
\hline \hline
\end{tabular}

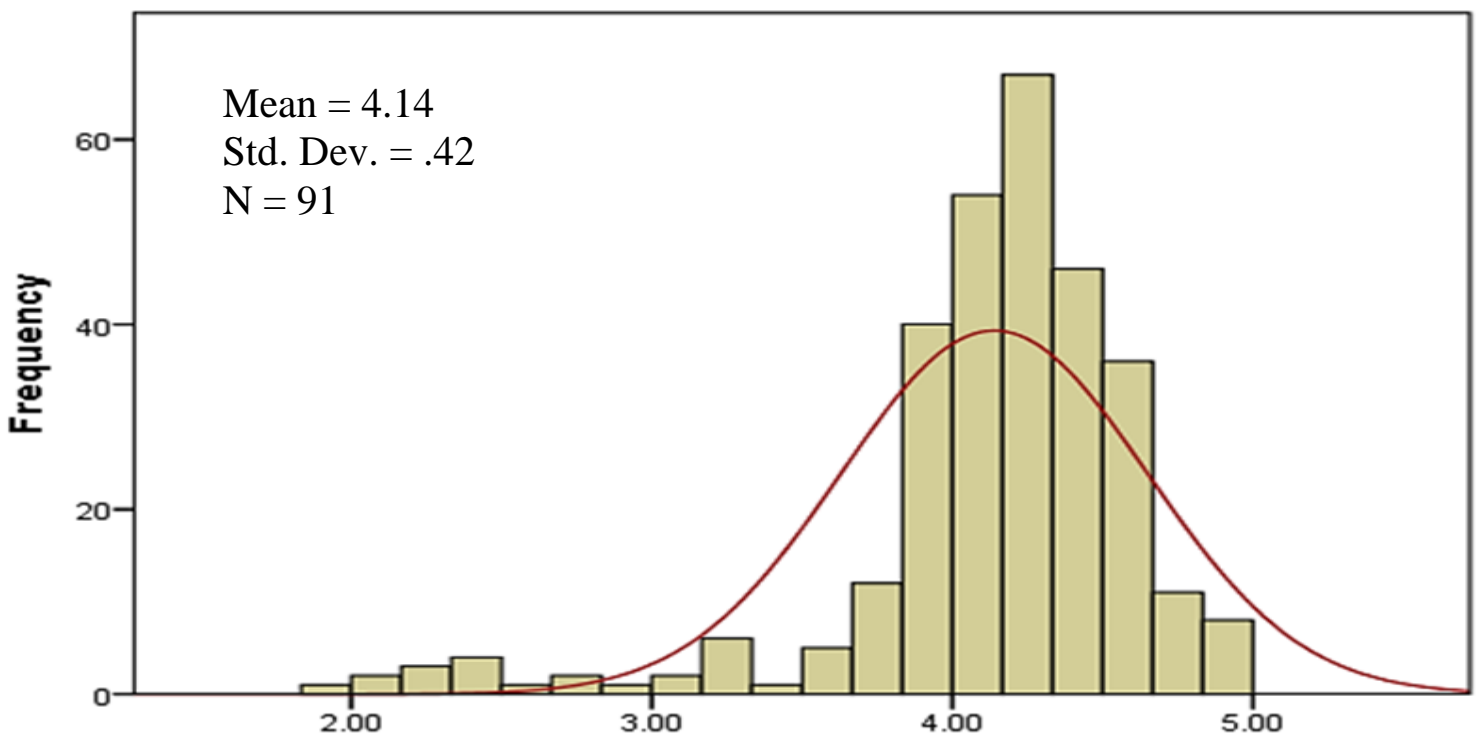

Figure 4.6 Histogram distributions for Accounting Information Quality 
Journal DOI: www.doi.org/10.46654/ij.24889849

Article DOI: www.doi.org/10.46654/ij.24889849.s76162

\section{Relevance}

Table 4.3 describes the distribution for the data on Relevance. This is the first dimension of Accounting information quality and describes the extent to which respondents consider themselves and their organizations as being participatory in the decision making process. The distributions for the variables are revealed to be significant and highly substantial, given the central tendencies for the indicators - RLV1: Were the primary outcomes defined and measured in a valid way, has a high mean $($ mean $=4.34)$ suggesting that respondents agree to the statement; RLV2: Were the accounting records adequately reported, has a significant mean (mean $=4.30$ ) affirming that majority of the respondents consider the statement as being a true position of their views; RLV3: Were the results consistent with prior known information, has a substantial mean (mean $=4.22$ ) which indicates that most of the respondents consider the statement to be correct. RLV4: Are the observed report treatment effects considered clinically meaningful, is associated with a high mean (mean $=4.45$ ) implying that a majority of the respondents believe the statement aligns with their own views too; RLV5: Is the report supported by the data and analysis presented, has a highly significant mean (mean $=4.19$ ) suggesting that most of the respondents identify with the statement. Indicating that a majority of the respondents affirm to the statement as being true.

Based on the evidence presented for the distribution, it is affirmed that all 5 of the indicators for Relevance are well and substantially manifested by the respondents and their respective organizations. This suggests the strong manifestation of Relevance as being well captured and evident within the sample of the study.

\section{Faithful representation}

Table 4.3 illustrates the distribution for Faithful representation. This is the second dimension for Accounting information quality and describes the extent to which the respondent or the organization engages in actions or activities that can be described as being customer friendly. The result from the analysis on the indicators presents them as having significant and high mean values. FFR1: The reports are usually in compliance with the industry standard, has a high mean (mean $=4.09$ ) indicating that in generality, respondents agree to the statement as being correct; FFR2: Variations in audited reports are very minute or curbed, has a significant mean (mean $=4.06$ ) suggesting that majority of the respondents affirm the statement as being true; FFR3: The company provides the information based on actual representation with little room for manipulation., has a high mean (mean $=4.33$ ) implying that majority of the respondents agree to the position of the statement; FFR4: The firm is well known for transparent reporting.; has a substantial mean (mean $=4.36$ ) suggesting that majority of the respondents are in agreement with the statement; FFR5: The accounting information usually reflects the nature of performance of the firm; has a mean (mean $=4.28$ ) implying that a substantial amount of the respondents agree significantly to the statement. The result form the analysis presents the target institutions as being highly consensually oriented. The implications are that majority of the firms consider themselves as being consensual in terms of decision making within their respective institutions/organization.

\section{Accounting information quality}

The distribution for Accounting information quality is based on the summaries of its dimensions $($ Relevance $=4.2741$, and Faithful representation $=4.2100$ ). The evidence from the analysis reveals that all dimensions on the average tend to be significantly manifested within the framework of the Nigerian quoted oil companies examined in this study. The 
Journal DOI: www.doi.org/10.46654/ij.24889849

Article DOI: www.doi.org/10.46654/ij.24889849.s76162

results depict both dimensions as having substantial mean values that can be described as substantial, suggesting that the Nigerian quoted oil companies are high in terms of decision making congruence patterns. The summaries for this two dimensions provide the approximation which is used in the assessment of the distribution for accounting information quality. The results depict Accounting information quality as being a significant feature in the reviewed Nigerian quoted oil companies examined. The data distribution for Accounting information quality is observed to be mean $=4.14$, indicating that the variable is considered by a majority of the respondents to be a strong feature of their institutions.

\section{Dimension Reduction}

It should be further identified that the study utilized dimension reduction, as all items under each dimension (i.e. relevance and faithful representation were statistically collapsed into a single principal component using factor analysis, it is therefore relevant to similarly show how well captured these items are in their respective using the confirmatory factor analysis.

Table 4.9: Confirmatory Factor analysis test using the Kaiser-Meyer-Olkin and Bartlett's Test

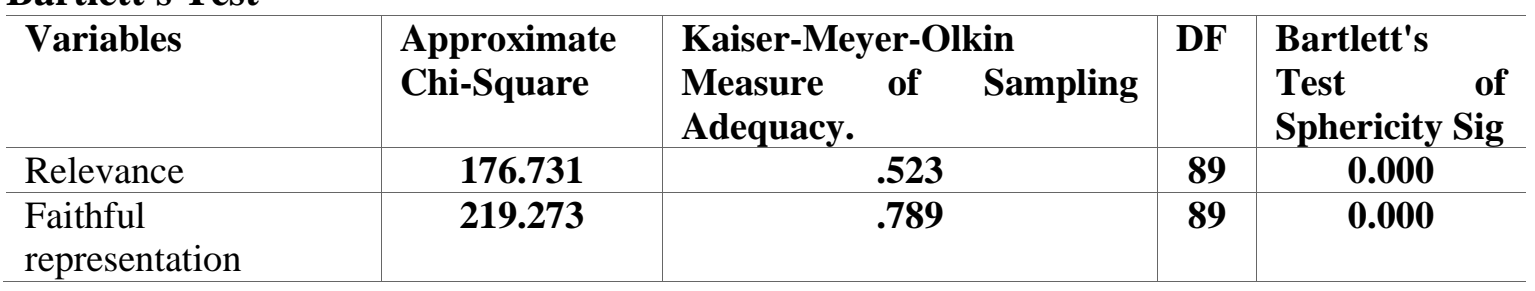

Using the Kaiser-Meyer-Olkin (KMO) and Bartlett's Test to evaluate and confirm the relevance of each dimension and measure factors, Table 4.9 above evaluates the confirmatory factor analysis of the topic. It can be identified that there is significant difference between the actual factors and observed factors based on their respective Approximate Chi-Square value which is observed to be above 0 . The highest of which can be attributable to faithful representation (219.273) while relevance shows the least discrepancy between expected and observed (176.731). Overall, all variables shows satisfactory level of variation.

The KMO measure of sample adequacy shows that all samples are significantly adequate. This is observed based on their various statistics. Although, the relatively least adequate sample is attributable to Relevance (.523) while Faithful representation shows that highest sample adequacy value of 0.789 . Overall, all employed sample are significantly adequate.

The KMO and Bartlett's test of sphericity test the hypothesis that the correlation matrix is an identity matric, which indicates that the employed variables are either related or unrelated and therefore suitable or unsuitable for structure detection. The output above shows all sampling adequacy to be approximately 1 . A threshold before which will show multicollinearity and autocorrelation between items of the same dimension/measure. The KMO (Kaiser-MeyerOlkin) of sampling size is greater than $50 \%(0.5)$ in all employed dimension and measures further showing that each principal component deduced from the myriad of items in the questionnaires are true representative of the questionnaire items and are therefore very reliable. The significance levels are all below $0.05(5 \%)$ which leads to the rejection of the null hypothesis of no structure detected. These therefore confirm the suitability of our principal components and as such shows the variables viable for subsequent tests. 
Journal DOI: www.doi.org/10.46654/ij.24889849

\section{Interpretations for Univariate Results}

The result on the distributions for the variables is interpreted in this section on the basis of their distributions and the extent to which they can be described as manifesting within the Nigerian quoted oil companies examined in the study.

Accounting information quality: The distributions and dimensions of Accounting information quality as well as its approximations (where mean $=4.14$ ) from its manifest properties suggest high mean distributions and as such evidence of Accounting information quality as a characteristic of the Nigerian quoted oil companies. The distributions indicate that the report of the various oil companies is relevant and faithfully represented.

Relevance: The evidence from the analysis suggests that the examined Nigerian quoted oil companies are highly participatory in their decision making process (mean $=4.2741)$. The evidence shows that majority of the Nigerian quoted oil companies thrive on a capacity to ensure everybody within the organization participates in institutional decision making process. The distribution suggests that there are continuous improvement programs that involve all key partners' interest.

Faithful representation: The result for Faithful representation suggests strong evidence of account faithful representation by the Nigerian quoted oil companies examined in the study. The distribution (mean $=4.2100$ ) shows that the Nigerian quoted oil companies are evidently open to ways of ensuring consensus in terms of every decision it takes. Based on the results, it can be seen that, there is more evidence of participatory than faithful representation making. First - Relevance $($ mean $=4.2741)$ and Second - Faithful representation (mean $=$ 4.2100).

\section{Test of Hypotheses}

$\mathbf{H}_{\mathbf{0 1}}$ : There is no significant relationship between Relevance and Return on Equity of oil companies in Nigeria.

Table 4.21 above illustrates the analysis for the association between relevance and earnings per share of Quoted oil companies. The findings show a significant association between both variables (where $\beta \geq 0.3, r>0.7$ and $p<0.05$ ). Thus, based on the criteria for null hypothetical statement acceptance, the null hypothesis was not supported. The empirical result is against the back drop of the work of Vako and Cular (2017) but in agreement with the findings of watts (2017) Zhang etal (2018) who found significant relationship between relevance and return on equity of oil companies in Nigeria.

H06: There is no significant relationship between Faithful Representation and Return on Equity of oil companies in Nigeria.

Table 4.21 above illustrates the analysis for the association between faithful representation and return on equity in Quoted oil companies. The findings show a very negative and significant association between both variables (where $\beta>0.3, r>0.7$ and $p<0.05$ ). Thus, the null hypothesis is rejected. Research works conducted in this area in developed economy of the world that are in agreement with this empirical results include Ziebart and Reiter (2002), Liao etal (2008), Aojimann and Watrin (2012) and Easton etal (2015). 
Journal DOI: www.doi.org/10.46654/ij.24889849

\section{Concluding Remark and Recommendations}

Many empirical literatures in finance and banking, accounting, economics, sociology and academic publication from various authors were critically reviewed in the course of this empirical work. The study is carried out in order to investigate the relationship between accounting information quality and quoted financial performance of oil and gas companies in Nigeria. Therefore, from the study results conducted, the empirical results interestingly provides evidence on the significant positive relationship between accounting information quality and quoted financial performance of oil and gas companies in Nigeria.

Having investigated theoretical and empirical issues, also considering the findings and conclusion, the following recommendations were made: There should be need for preparers of accounting information to improve on the accounting information quality devoid of window dressing and creative accounting, regular disclosure, transparency and accountability of such accounting information is required since investors are sensitive to qualitative and quantitative accounting information in assessing the performance of quoted oil companies in and outside Nigeria.

Also in line with qualitative and quantitative of accounting information quality, financial statements of quoted oil companies in Nigeria should be prepared and presented according to laid down regulations and ethical standards duly observed to ensure accounting information presented for among users, most and public consumption do represent the oil companies' economic reality during reported periods.

\section{Limitation and Suggestion for further studies}

Every empirical study of this magnitude cannot be without certain limitation with regards to the variables, methodology and years of study. This empirical study is limited to relevance, faithful representation and return on equity of quoted oil and gas companies in Nigeria, adopting primary data. Further studies should adopt more sub-variable of quantitative accounting information quality and quoted financial performance, adopting mixed method of analysis for a more rebust empirical results. 
Journal DOI: www.doi.org/10.46654/ij.24889849

\section{References}

Ahmad, S., Siddiqui, K.A \&, Aboplsawh, H.M(2020). Family SME's survival: The role of owner. Family and Corporate Social responsibility. Journal of Small Business and Enterprise Development, 27(2),281-297

Akanbi, T.A, \& Adewoye, J. (2018). Effects of Accounting information system adoption on the financial performance of commercial bank in Nigeria. Journal of Accounting \& Marketing, 1(6), 1-6

Akesinro, S. \& Adetoso, J. (2016). The effects of computerized accounting system on the performance of banks in Nigeria. Journal of Economics and Sustainable Development, $7(14), 76-82$

Al-Dalabih F.A (2018). The impact of the use of accounting information system on the quality of financial data. International Business Research, 11(5), 143-158

Ali, B., Bakar, R \& Omar, W(2016). The critical success factors of Accounting Information System (AIS) and its impact on organizational performance of Jordan commercial banks International Journal of Economics, Commerce and Management, 4(4),658-677

Alnajjar, M(2017). Impact of Accounting information system on organizational performance: A study of SME's in the UAE. Journal of Accounting \& Finance, 3(1),2035

Borhan, O \& Nofees, A (2018). Effects of accounting information system on financial performance: A study of selected real estate companies in Jordan. India Technical Research Organization, 5(1),41-50

Budairi .J.G (2017). The effect of quality of accounting information on financial statements on the decisions of its users, an applied study in a group of Iraqi companies. Al-Ghari Journal of Economic and Administrative Sciences 14(1),355-388

Dandago, K. Rafai, A (2014). Information technology and accounting system in the Nigerian banking industry. Asian Economic and Financial Review, 2(10), 1-9

Dekeng, S. \& Prabowo, M (2015). Accounting information system alignment and Smes performance. A literature Review. International Journal of Management, Economics \& Social Sciences, 4(2),58-70

Denos, P., Holt, D.L. \& Imholf, E.A. (2019). The use of accounting information in bank lending decisions Accounting, Organizations and Society, 14(3), 235-246

Eb, A., Pretorious, P \& Zuva, T 92013). The role of accounting information system in accounting firm. International Journal of Accounting, Advanced Computer Research, $1(2), 21-31$

Esmeray, A (2016). The impact of accounting information systems in firm performance: Empirical evidence in Turkish small and medium sized enterprises. International Review of Management and Marketing, 6(2),233-236

Farah, N., Farrukh, I \& Faizan, N92016). Financial performance of firms: Evidence from Pakistan Cement industry Journal of Teaching and Education, 5(1),81-94

Hla, D \& Teru, S (2015). Efficiency of accounting information system and performance measures: Literature Review International Journal of Multidisciplinary and Current Research, 3(3),976-984

Ironkwe U.I. \& Nwaiwu, J.N(2018). Accounting information system on financial and Nonfinancial measures of companies in Nigeria. International Journal of Advanced Academic Research/Business Development \& Management, 4(2),39-55

Isa, A (2017. The impact of computerized accounting information system on management performance in public sector in Nigeria: Problem and Prospects. International Journal of Multidisciplinary Research and Development, 4(1),80-83 
Journal DOI: www.doi.org/10.46654/ij.24889849

Kashif, B (2018). Impact of Accounting Information system on the financial performance of selected FMCG companies. Asian Journal of Allied Sciences and Technology, 2(3),817

Khan,A (2017). Impact of Accounting information system on the organizational performance: A case study of Procter and Gamble. Star Research, 5(12),20-30

Mahdi, S., Mahmond, L., Mostafa, B. \& Ebadohollah, T (2015). The effect of implementation of accounting information system on efficiency, profitability and productivity of SMEs in Iran. Banks and Bank Systems, 10(3),79-86

Manchdot, T. (2019). A review of determinants Accounting information system adoption. Science Journal of Business Management, 7(1),17-22

Mitchell, T. Biykan, A. Oniken, G \& Fiedler, F (2017). The contingency model: Criticism and suggestion Academy of Management Journal, 13(3),1-23

Nizor, S., Ahmad, F \& Mohamad,M.(2016). Evaluate of accounting information systems in meeting the requirements of financial and managerial performance. Field study in the United Arab Emirates private Hospitals. International Journal of Humanities and Social Science, 6(4), 170-196

Obaidat A/N (2017). Accounting information qualitative characteristics gap: Evidence from Jordan International Management Review, 3(2),26-32

Odar, M., Kravic, S \& Jermon M. (2015). The role of management Accounting system in decision-making process: Evidence from a post-transactions economy. Engineering Economics, 26(1),84-92

Palazuelos, E., Crespo, A.H \& Delcorte, Z.M (2017). Accounting information and trust as determinants of credit granting to SMEs: The role of external audit. Small Business Economics, 51(4),861-877

Patal, S (2015). Effects of accounting information system on organizational profitability. International Journal of Research and Analytical Reviews, 2(1),72-77

Raed, K (2017). The impact of computerized accounting information system on management performance in public sector in Nigeria: problem \& Prospects. International Journal of Multidisciplinary Research and Development, 4(12),80-83

Rehab, U (2018). The impact of Accounting information systems on organizational performance. The context of Saudi's SMEs. International Review of Management and Marketing, 8(2),69-73.

Saeidi, H (2014). The impact of accounting information system on financial performance. A case study of TCS India. Indian Journal of Fundamental and Applied Life Sciences, $4(4), 412-417$

Samer,M (2016). The impact of the effectiveness of accounting information systems on operational performance in public listed industrial companies in Jordan. Journal of Social Sciences, 5(3),265-276

Taiwo, J (2016). Effect of ICT on accounting information systems and organizational performance: The application of information and communication technology on accounting information system European Journal of Business and Social Sciences, $5(2), 1-15$

Tera, S., IdoNdeyati, J (2017). A review of the impact of accounting information system for effective internal control on firm performance. Indian Journal of Finance and Banking, $1(2), 52-59$

Yaser, H., Mina, S \& Nor, A (2014). The impact of the effectiveness of accounting information system in Nigerian banking industries. Asian Economic and Financial Review, 4(5), 655-670 